\title{
What Determines Hatchling Weight: Breeder Age or Incubated Egg Weight?'
}

Technical Note

\section{-Author(s)}

Traldi $A B^{2}$

Menten JFM ${ }^{3}$

Silva $\mathrm{CS}^{2}$

Rizzo PV²

Pereira PWZ2

Santarosa $J^{2}$

1 Part of the Ph.D. thesis of the first author. Some results of this study were presented in. APINCO 2009 Conference, Porto Alegre, RS, Brazil (Lamas Award - Production).

2 Post-graduation students - graduação Departamento de Zootecnia - ESALQ/USP, Brazil.

3 Head professor - Departamento de Zootecnia - ESALQ/USP, Brazil.

\section{-Mail Adress}

Ana Beatriz Traldi

Departamento de Zootecnia - ESALQ/USP

Avenida Pádua Dias, $\mathrm{n}^{\circ} 11$

13.418-900. Piracicaba, SP, Brazil

E-mail: beatriztraldi@ig.com.br

\section{-Keywords}

Albumen, eggshell, hatchling weight, incubation, yolk.

\section{-Acknowledgements}

The authors thank Granja Santo Antônio for incubating the eggs, FAPESP for funding the study, and CAPES for the scholarship granted to the first author.

\section{ABSTRACT}

Two experiments were carried out to determine which factor influences weight at hatch of broiler chicks: breeder age or incubated egg weight. In Experiment 1, 2340 eggs produced by 29- and 55-weekold Ross ${ }^{\circledR}$ broiler breeders were incubated. The eggs selected for incubation weighed one standard deviation below and above average egg weight. In Experiment 2, 2160 eggs weighing $62 \mathrm{~g}$ produced by breeders of both ages were incubated. In both experiments, 50 additional eggs within the weight interval determined for each breeder age were weighed, broken, and their components were separated and weighed. At hatch, hatchlings were sexed and weighed, determining the average initial weight of the progeny of each breeder age. Data were analyzed using the Analyst program of $\mathrm{SAS}^{\circledR}$ software package. In Experiment 1, the weight difference between eggs produced by young and mature breeders was $10.92 \mathrm{~g}$, and the component that mostly influenced this difference was the yolk $(7.51 \mathrm{~g}$ heavier in mature breeders, compared with $4.23 \mathrm{~g}$ difference in albumen and $0.8 \mathrm{~g}$ in eggshell weights). Hatchling weight difference was $9.4 \mathrm{~g}$ higher in eggs from mature breeders. In Experiment 2, egg weight difference was only $0.74 \mathrm{~g}$, but yolk weight was $4.59 \mathrm{~g}$ higher in the eggs of mature breeders. The results obtained in the present study indicate that hatchling weight is influenced by egg weight, and not by breeder age.

\section{INTRODUCTION}

A chicken egg generally consists of $58.5 \%$ albumen, $31 \%$ yolk, and $10.5 \%$ shell, but this composition varies according to genetic strain and breeder age (Vieira \& Moran, 1999).

Chick weight at hatch is directly related to egg weight, corresponding to 62 to $76 \%$ of egg weight. This correlation between increases after the 11 th day of incubation and may remain the same during the entire rearing period (Wilson, 1991).

Breeder age strongly influences egg weight, as well as egg quality and composition. Young breeders tend to produce lighter eggs, and consequently, lighter day-old chicks (Dalanezi et al., 2004); however, egg with the same weight can be produced by breeders of different ages as well breeders of the same age can produce eggs with different weights. Some studies showed that chick weight is independent of breeder age and it is only influenced by egg weight (Pinchasov, 1991).

Egg weight increases with breeder age due to the increase in yolk size, whereas the variation in the weight of the eggs produced by breeders of the same age results from an increase in albumen proportion (Lima et al., 2001). It must be mentioned that eggs with the same weight, independently of breeder age, produce day-old chicks with the same weight and quality. 
Eggs produced by breeders of different ages require the same incubation time, but not the same temperature (Almeida et al., 2006), as eggs from older breeders tend to produce more heat during incubation than those from younger breeders. Also, as the embryo develops, its metabolic heat production increases, which demands lowering the temperature supplied by the incubator. Overheating embryos negatively affects hatch, as well as the development of the chick's digestive and immune systems (Valle, 2008).

Considering the influence of hatchling weight on the overall performance of a broiler flock, the objective of the present study was to determine, by evaluating the weights of whole eggs, their components and of hatchlings produced by 29- or 55-week-old breeders, what has the strongest influence on initial weight: breeder age or incubated egg weight.

\section{MATERIALS AND METHODS}

Two experiments were carried out with two flocks of Ross ${ }^{\circledR}$ broilers breeders of different ages (29 and 55 weeks old) each. In Experiment I, 2340 eggs were incubated (1200 and 1140 eggs from young and mature breeders with different body weights, respectively). Eggs weighed one standard deviation below and above average egg weight, representing $66 \%$ of the population produced by each flock, obtained from a commercial breeder farm.

In Experiment 2, 2160 eggs (1080 eggs from young and mature breeders with similar body weight). Egg weight was standardized to approximately $62 \mathrm{~g}$ for both breeder ages, representing around $25 \%$ of the egg population in each flock.

The experiments were carried out for 13 weeks. In order to determine the weight of the eggs to be selected for incubation, 100 eggs were initially sampled for each breeder age, individually weighed, and egg weight mean and standard deviation were calculated. After the determination of egg weights to be selected, eggs produced by breeders of each age were individually weighed, classified according to weight interval and placed in incubation trays, each with a capacity of 30 eggs. Trays were weighed to determine the mean weight of eggs effectively incubated. Eggs were incubated in a commercial hatchery for 18 days in a single trolley in multiple-stage setter, and later transferred to a single hatcher.

In each experiment, 50 eggs within the weight interval determined for each breeder age were selected, weighed, broken, and the yolk, albumen and eggshell were separated and weighed to obtain their absolute and relative (\% of egg weight) weights for each breeder age. These data were statistically analyzed using the Analyst program of $\mathrm{SAS}^{\circledR}$ statistical package.

At hatch, chicks from each breeder flock were sexed and weighed to obtain the average weight of males and females produced by young and mature breeders. Six chicks per breeder age were sacrificed, and their yolk sac was removed and weighed to determine residual yolk content.

\section{RESULTS AND DISCUSSION}

Average egg weight, egg components weight, and day-old chick weight produced by young (29 weeks) and mature (55 weeks) breeders in each experiment are shown in Table 1.

In Experiment 1, the eggs produced by 55-weekold breeders presented higher average weight than those produced by 29-week-old breeders. Although all egg components were heavier in the eggs of mature breeders, the largest weight difference obtained between breeder ages was the yolk. In this experiment, the average weights of male and female chicks derived from 29- and 55-week-old breeders were 38.6 and $48.0 \mathrm{~g}$, respectively, representing a $9.4 \mathrm{~g}$ difference in initial weight, whereas egg weight different was around $11.0 \mathrm{~g}$. Because yolk sac weight at hatch was similar between breeder ages, it may be inferred that residual yolk content did not influence initial chick weight.

The hatchability, determined as the percentage of hatched eggs relative to the number of set eggs, was similar between breeder ages.

In Experiment 2, although egg weights were statistically different, this does not have any practical meaning as this difference may have been detected by the high number of observations used in the analysis. Therefore, egg weight may be considered similar (62.03 vs. $62.77 \mathrm{~g})$, as the weight difference was of merely $0.74 \mathrm{~g}$.

Although the eggs of 55-week-old breeders presented higher yolk weight, this did not influence hatchling weight $(43.4 \mathrm{~g}$ and $43.0 \mathrm{~g}$, respectively, for 29- and 55-week-old breeder eggs). This indicates that hatchling weight is affected only by egg weight, independently of yolk weight and breeder age. Yolk sac weight, as previously observed in Experiment 1, was similar between hatchlings derived from young and mature breeders, and did not influence initial weigh. 
Hatchability (percentage of hatched eggs relative to the number of set eggs) of eggs produced by mature breeders was $8.3 \%$ lower compared with the eggs of young breeders. Although the cause of this lower hatchability was not investigated in the present study, it is possible that the temperature of the multiple-stage machine was adequate for the eggs of 29-week-old breeders, but high for those of 55-week-old breeders, causing late embryo mortality (Campos, 2000).

Table 1 - Average weight of eggs ( $n=50)$, egg components and day-old chicks derived from breeders of two different ages in Experiments 1 and 2 .

\begin{tabular}{|c|c|c|c|c|c|}
\hline \multicolumn{6}{|l|}{ Experiment 1} \\
\hline \multirow{2}{*}{\multicolumn{2}{|c|}{ Parameters }} & \multicolumn{2}{|c|}{$\begin{array}{l}\text { Breeder age } \\
\text { (weeks) }\end{array}$} & \multirow[t]{2}{*}{$p$ value } & \multirow[t]{2}{*}{$\mathrm{CV}^{1}$} \\
\hline & & 29 & 55 & & \\
\hline Eggs (g) & & $57.84 b$ & $68.76 a$ & $<0.0001$ & 2.64 \\
\hline Albumen (g) & & $34.72 b$ & $38.95 a$ & $<0.0001$ & 5.36 \\
\hline Albumen (\%) & & $59.82 b$ & $55.25 a$ & $<0.0001$ & 4.29 \\
\hline Yolk (g) & & $15.48 \mathrm{~b}$ & $22.99 a$ & $<0.0001$ & 7.03 \\
\hline Yolk (\%) & & $26.67 b$ & $32.64 a$ & $<0.0001$ & 7.03 \\
\hline Eggshell (g) & & $7.27 b$ & $8.07 a$ & $<0.0001$ & 7.62 \\
\hline Eggshell (\%) & & $12.53 b$ & $11.45 \mathrm{a}$ & $<0.0001$ & 7.48 \\
\hline Hatchability (\%) & & 87.50 & 86.50 & .. & .. \\
\hline \multirow[t]{3}{*}{ Day-old chicks (g) } & Males & 40.00 & 48.40 & .. & .. \\
\hline & Females & 37.20 & 47.60 & .. & .. \\
\hline & Mean & 38.60 & 48.00 & & \\
\hline Yolk sac at hatch (g) & & 4.370 & 4.932 & $>0.5000$ & $>0.5000$ \\
\hline \multicolumn{6}{|l|}{ Experiment 2} \\
\hline \multirow[t]{2}{*}{ Parameters } & & \multicolumn{2}{|c|}{$\begin{array}{c}\text { Breeder age } \\
\text { (weeks) }\end{array}$} & & $\mathrm{CV}^{1}$ \\
\hline & & 29 & 55 & & \\
\hline Eggs (g) & & $62.03 b$ & $62.77 a$ & 0.0085 & 2.95 \\
\hline Albumen (g) & & $36.76 a$ & $34.33 b$ & $<0.0001$ & 4.96 \\
\hline Albumen (\%) & & $60.84 a$ & $54.81 b$ & $<0.0001$ & 3.45 \\
\hline Yolk (g) & & $16.11 \mathrm{~b}$ & $20.70 a$ & $<0.0001$ & 6.38 \\
\hline Yolk (\%) & & $26.68 b$ & $33.06 a$ & $<0.0001$ & 6.22 \\
\hline Eggshell (g) & & 7.33 & 7.52 & 0.7585 & 10.0 \\
\hline Eggshell (\%) & & 12.14 & 12.02 & 0.6308 & 9.87 \\
\hline Hatchability (\%) & & 85.20 & 76.90 & & \\
\hline \multirow[t]{3}{*}{ Day-old chicks (g) } & Males & 43.50 & 43.20 & .. & .. \\
\hline & Females & 43.20 & 42.70 & 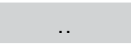 & .. \\
\hline & Mean & 43.40 & 43.00 & & \\
\hline Yolk sac at hatch $(\mathrm{g})$ & & 4.925 & 4.228 & $>0.5000$ & $>0.5000$ \\
\hline
\end{tabular}

Means followed by different letters in the same row are different by the $F$ test $(p<0.05) .1$ - Coefficient of variation (\%).

In both experiments, the composition of the eggs produced by young and mature breeders was different, but hatchling weight relative to egg weight was similar, varying between 67 and $70 \%$, which is consistent with the interval of 62 to $76 \%$ reported in literature (Wilson, 1991). Therefore, egg composition does not seem to influence hatchling weight. The differences in albumen and yolk proportions in the eggs produced by breeders of different ages, considering the differences in protein, lipid, vitamin, mineral, and water content, may result in different body composition and different tissue and organ development of the resulting chicks. However, this was not determined in the present study, and the influence of these factor on broiler development warrants further research.

\section{CONCLUSION}

The results obtained in the present study indicate that hatchling weight is influenced by egg weight, and not by breeder age, as eggs with similar weights results in hatchlings with similar weight.

\section{REFERENCES}

Almeida JG, Dalhke F, Maiorka A, Faria Filho DE, Oelke CA. Efeito da idade da matriz no tempo de eclosão, tempo de permanência do neonato no nascedouro e peso do pintainho. Archives of Veterinary Science 2006; 11(1):45-49.

Campos EJ. A incubação artificial. In: Campos EJ. Avicultura: razões, fatos e divergências. Belo Horizonte: FEP-MVZ 2000; v.7, p.203-310.

Dalanezi JA, Mendes AA, Garcia EA, Garcia RG, Moreira J, Takita TS, Paz ICLA. Efeito da idade da matriz sobre o rendimento e qualidade da carne de frangos de corte. Revista Brasileira de Ciência Avícola, Campinas 2004; 24(4):685-690.

Lima AA, Vieira SL, Corteling J. Eclodibilidade de ovos oriundos de matrizes com extremos em idade e de pesos diferentes. Revista Brasileira de Ciência Avícola 2001; 3(3):86-94.

Pinchasov Y. Relationship between the weight of hatching eggs and subsequent early performance of broiler chicks. British Poultry Science $1991 ; 32: 109-11$.

Statistical Analyses System. User's guide [CD-ROM]. Cary; 2000.

Valle R. Como obter bons pesos na primeira semana em frangos de corte [circular técnica]. Aviagen Brasil; 2008.

Vieira SL, Moran ET. Broiler yields using chicks from extremes in hatching egg weight of diverse strains. Journal of Applied Poultry Research1999; (7):339-346

Wilson HR. Interrelationships of egg size, chick size, posthatching growth and hatchability. World's Poultry Science Journal 1991; 1(47):5-20. 